\title{
The structure and function of human IgA
}

\author{
Michael A. KERR \\ Department of Pathology, University of Dundee, Ninewells Hospital Medical School, Dundee DD1 9SY, U.K.
}

\section{INTRODUCTION}

IgA is present in normal human serum at about one-fifth of the concentration of IgG. However, it is catabolized around five times faster than IgG and therefore the rates of synthesis of the two immunoglobulins must be similar [1]. $\operatorname{IgA}$ is the most abundant immunoglobulin in secretions. Secretory $\operatorname{IgA}(\mathbf{S I g A})$ is the product of local synthesis at the mucosal surfaces which are the main source of antigenic material for the body. In mucosal tissue, IgA synthesis far exceeds that of other classes. As a result, in man, more IgA is produced than all other immunoglobulin classes combined. In contrast to other immunoglobulins, human IgA displays a unique heterogeneity in its molecular forms, each with a characteristic distribution in various body fluids [2]. Human IgA occurs in two isotypic forms, IgA1 and IgA2, with $\operatorname{IgA} 2$ existing as two allotypic variants $\operatorname{IgA} 2 \mathrm{~m}(1)$ and $\operatorname{IgA} 2 \mathrm{~m}(2)$. Each of these forms is found in various degrees of aggregation.

Although the importance of $\operatorname{IgA}$ in mucosal secretions is well established, it is now clear that in humans much of the $\operatorname{IgA}$ is secreted directly into the blood and never reaches the mucosal surfaces [3]. Serum IgA is predominantly monomeric $\operatorname{IgA} 1$ which is produced in the bone marrow, while in external secretions most of the locally produced $\operatorname{IgA}$ is polymeric with a relative increase in the proportion of $\operatorname{IgA} 2[4,5]$. The lymphocytes which produce monomeric or polymeric $\operatorname{IgA}, \operatorname{IgA} 1$ or $\operatorname{IgA} 2$ are characteristically distributed in various lymphoid and nonlymphoid tissues. The differential interaction of monomeric and polymeric IgA molecules with various cells leads to their selective distribution in body fluids and possibly to differences in their effector functions. Secretory and serum IgA are therefore molecules with different biochemical and immunochemical properties produced by cells with different organ distributions.

Table 1. Distribution of IgA and IgG in serum and secretions

Abridged and modified from $[1,2,4,6]$. Abbreviation: n.d., not determined.

\begin{tabular}{lcccc}
\hline & \multicolumn{2}{c}{$\begin{array}{c}\text { Concentration } \\
\text { (mg/100 ml) }\end{array}$} & & \\
\cline { 2 - 3 } Fluid & IgG & IgA & $\begin{array}{c}\text { Polymeric } \\
\text { IgA (\%) }\end{array}$ & $\begin{array}{c}\text { Ratio } \\
\text { IgA1/IgA2 }\end{array}$ \\
\hline Serum & 1230 & 328 & 13 & $89: 11$ \\
Colostrum & 10 & 1234 & 96 & $65: 35$ \\
Whole saliva & 4.9 & 30.4 & 96 & $63: 37$ \\
Jejunal fluid & 34 & 27.6 & 95 & $70: 30$ \\
Colonic fluid & 86 & 82.7 & n.d. & $35: 65$ \\
Hepatic bile & 18.2 & 10.5 & 65 & $74: 26$ \\
Nasal fluid & 5.8 & 25.7 & n.d. & $95: 5$ \\
Bronchial & 1.8 & n.d. & 82 & $67: 33$ \\
& & & &
\end{tabular}

The high concentration of monomeric serum $\operatorname{IgA}$ is unique to man, most laboratory animals having much lower concentrations of serum $\operatorname{IgA}$ which is predominantly polymeric [6]. Various methods of immunization can induce an immune response of serum and/or secretory $\operatorname{IgA}[7,8]$. Although most of the serum IgA is monomeric, recent studies indicate that specific serum IgA antibodies induced by either mucosal or systemic immunizations with microbial or dietary antigens can appear first in the dimeric form $[9,10]$. The synthesis of $\operatorname{IgA}$ and its control has been the main subject of other reviews $[5,11,12]$ and therefore it will not be covered here in detail. This review will concentrate on the structure of the different species of $\operatorname{IgA}$ and on biochemistry of their interactions with other proteins, both humoral and cellular, which are pertinent to the effector functions of the molecule.

In spite of its abundance, relatively little is known about the functions of IgA. The biochemical characterization of the different forms of $\operatorname{IgA}$, the improvement in methods of purification and the availability of monoclonal antibodies against each isotype has allowed a reappraisal of the immunology of these proteins. Recent research suggests a more active role in immunity than previously considered. Serum $\operatorname{IgA}$ had been shown to prevent activation of the complement system and to inhibit phagocytosis, chemotaxis and antibody-dependent cellular cytotoxicity [13-15]. These results suggested that the predominant role of serum $\operatorname{IgA}$ was the removal of antigenic substances without the generation of an inflammatory response. However, more recent work has shown that $\operatorname{IgA}$ can activate complement and will efficiently trigger cell-mediated events [16-18].

The idea of a passive role for serum $\operatorname{IgA}$ in immunity was reinforced by the observation that $\operatorname{IgA}$ deficiency is relatively common and is not usually associated with markedly impaired resistance to infection [19]. There is however, compelling evidence for an important role for secretory $\operatorname{IgA}$ in immunity [20-22]. Furthermore, serum IgA levels are frequently raised in rheumatic diseases and in other autoimmune diseases as well as in liver disease and persistent infections such as bacterial endocarditis and AIDS [23-25]. Elevated IgA levels are associated with rises in serum polymeric $\operatorname{IgA}$, circulating $\operatorname{IgA}$-containing immune complexes and $\operatorname{IgA}$ rheumatoid factor. Immune complexes containing $\operatorname{IgA}$ have been suggested to be pathogenic in these and other diseases such as IgA nephropathy, a common cause of kidney failure $[26,27]$.

\section{THE STRUCTURE OF IgA}

Monomeric IgA comprises two heavy and two light chains, the light chains being the same as those found in other immunoglobulins. Electron microscopy suggests the common $Y$-shaped structure [28]. The heavy or $\alpha$ chain has a molecular mass of

Abbreviations used: ADCC, antibody-dependent cellular cytotoxicity; BSA, bovine serum albumin; IgA-R, IgA receptor; IgA-BF, soluble IgA binding factor; LPS, lipopolysaccharide; SC, secretory component; sIgA, secretory IgA; $\operatorname{dIgA}$, dimeric $\operatorname{IgA}$; pIgA, polymeric IgA. 
around $60 \mathrm{kDa}$, slightly larger than that of $\operatorname{IgG}$ because of its heavier glycosylation. Like the heavy chains of IgG and IgD, it is made up of four domains, a variable domain and three constant domains; $\mathrm{C}_{\mathrm{H}} 1, \mathrm{C}_{\mathrm{H}} 2$ and $\mathrm{C}_{\mathrm{H}} 3$. IgA is more negatively charged than most of the IgG, having $\beta$ mobility on electrophoresis.

Human serum IgA occurs mainly in the monomeric, $160 \mathrm{kDa}$, 6.5-7.0 S form. A small amount of serum $\operatorname{IgA}$ is found in polymeric forms, usually dimers, linked by disulphide bonds and by an additional, cysteine-rich polypeptide termed $J$ chain $(16 \mathrm{kDa})$. Monomeric IgA is also found in most secretions, but the dimeric (11 S) form predominates. Higher aggregation states, particularly tetramers, are also found in some secretions. The polymeric secretory IgA comprises not only $\operatorname{IgA}$ and $\mathrm{J}$ chain but also a heavily glycosylated protein called secretory component (SC), which is complexed with the $\operatorname{IgA}$ during the secretion process. It is part of a cell surface polymeric Ig receptor which mediates the transcytosis of polymeric IgA and IgM across the epithelial cell barrier (see below). SC and $J$ chain are both disulphide-linked to the Fc region of the $\operatorname{IgA}$, although not to one another.

The amino acid sequences of IgAs from man, mouse and rabbit have been determined or deduced [29-34]. They show around $50 \%$ homology. Although all of the intradomain disulphide bonds appear to be conserved, some cysteines, probably involved in interchain disulphide bonds, are not. The $C$-terminus of the $\alpha$ chain, like that of the $\mu$ chain, extends 18 amino acids relative to that of other heavy chains, with a penultimate cysteine residue which is linked to $\mathbf{J}$ chain in polymeric forms [35]. In monomeric forms, this penultimate cysteine can apparently form a disulphide bond with the homologous cysteine on the other $\alpha$ chain, another cysteine in the other $\alpha$ chain or occasionally with other, non-immunoglobulin proteins, such as albumin or $\alpha_{1}$ antitrypsin. In dimeric forms the individual monomers are linked by disulphide bonds utilizing this penultimate cysteine residue. The other cysteine which makes up this pair is the subject of some debate, but it is probably Cys-311 on the $C_{H} 2$ domain [36]. It is possible that studies on myelomas which show greater tendency to polymerize might not reflect the normal situation.

Human IgA1 and IgA2 heavy chains differ in only 22 amino acids, predominantly due to a deletion in IgA 2 of 13 amino acids in the hinge region (Fig. 1). The hinge region of IgA1 is composed of an unusual repeating sequence rich in proline, serine and threonine, the serines carrying $O$-linked sugars. The lack of this region in IgA2 makes it resistant to the action of a number of bacterial proteinases which cleave $\operatorname{IgA} 1$ in the hinge region and

\begin{tabular}{|c|c|c|c|c|}
\hline & \multirow[b]{2}{*}{ Residue } & \multirow[b]{2}{*}{$\operatorname{IgA} 1^{a}$} & \multicolumn{2}{|c|}{ IgA2 } \\
\hline & & & $\mathrm{A} 2 \mathrm{~m}(1)^{b}$ & $\mathrm{~A} 2 \mathrm{~m}(2)^{c}$ \\
\hline \multirow[t]{10}{*}{$\mathrm{CH} 1$ domain } & 133 & Cys & Asp & Asp \\
\hline & 136 & Gln & Pro & Pro \\
\hline & 137 & Pro & Gln & Gln \\
\hline & 143 & Ile & Val & Val \\
\hline & 166 & Gly & Asn GlcNAc-X & Asn GlcNAc-X \\
\hline & 197 & Leu & Pro & Pro \\
\hline & 198 & Ala & Asp & Asp \\
\hline & 211 & Asn & Asn & Asn GlcNAc-X \\
\hline & 212 & Pro & Pro & Ser \\
\hline & 221 & Pro & Pro & Arg \\
\hline \multirow[t]{17}{*}{ Hinge region } & 223 & Pro & & \\
\hline & 224 & Ser GalNAc & & \\
\hline & 225 & Thr & & \\
\hline & 226 & Pro & & \\
\hline & 227 & Pro & & \\
\hline & 228 & Thr & & \\
\hline & 229 & Pro & & \\
\hline & 230 & Ser GalNAc-Gal & Deletion & \\
\hline & 231 & Pro & & \\
\hline & 232 & Ser GalNAc-Gal & & \\
\hline & 233 & Thr & & \\
\hline & 234 & Pro & & \\
\hline & 235 & Pro & & \\
\hline & 236 & Thr & Pro & Pro \\
\hline & 238 & Ser GalNAc-Gal & Pro & Pro \\
\hline & 240 & Ser GalNAc-Gal & Pro & Pro \\
\hline & 263 & Asn GlcNAc-X & Asn GlcNAc-X & Asn GlcNAc-X \\
\hline \multirow[t]{7}{*}{$\mathrm{CH} 2$} & 277 & Val & Ala & Ala \\
\hline & 319 & Lys & Glu & Glu \\
\hline & 327 & Tyr & His & His \\
\hline & 330 & Ser & Leu & Leu \\
\hline & 337 & Thr & Asn GlcNAc-X & Asn GlcNAc-X \\
\hline & 338 & Leu & Ile & Ile. \\
\hline & 339 & Ser & Thr & Thr \\
\hline \multirow[t]{5}{*}{$\mathrm{CH} 3$} & 411 & Phe & Phe & Tyr \\
\hline & 428 & Asp & Asp & Gln \\
\hline & 458 & $\mathrm{Val}$ & Val & Ile \\
\hline & 459 & Asn GlcNAc-X & Asn GlcNAc-X & Asn GlcNAc-X \\
\hline & 467 & Val & Val & Ala \\
\hline
\end{tabular}

Fig. 1. Differences in the amino acid sequence and carbohydrate structure of the C-regions of the human $\alpha_{1}$ and two allotypes of $\alpha_{2}$ chains

Residues are numbered according to sequence determined for the $\alpha$ chain of IgA1 Bur [29]. Sequences are those of ${ }^{a} \mathrm{IgA1}$ Bur, ${ }^{b} \mathrm{IgA} 2 \mathrm{Lan}$ [30], ${ }^{c}$ IgA2 But [31]. 


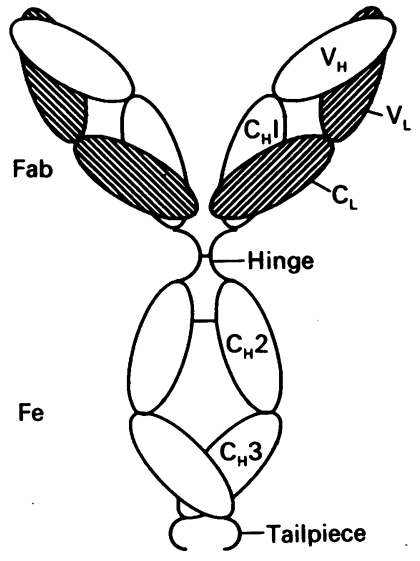

$\lg A 1$

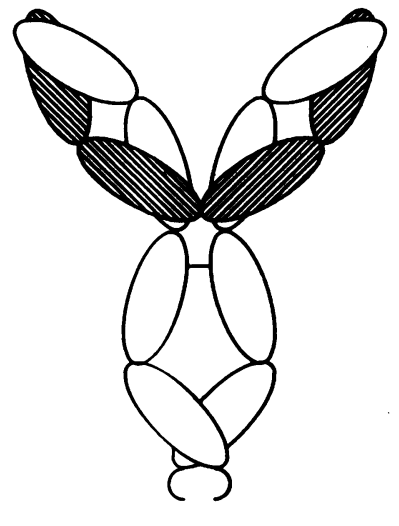

$\lg A 2 m(1)$

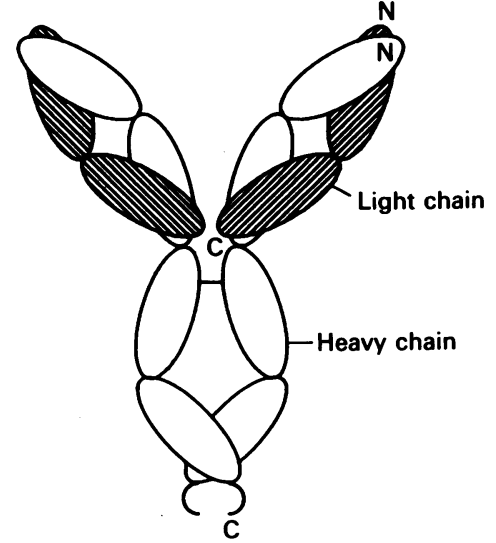

$\lg A 2 m(2)$

\section{Fig. 2. Structures of monomeric $\operatorname{IgA1}, \operatorname{IgA} 2 \mathrm{~m}(1)$ and $\operatorname{IgA2m}(2)$}

These theoretical models are based on the known structure of IgG. They show unpaired $\mathrm{C}_{\mathrm{H}} 2$ domains held apart by carbohydrate. The linear extensions or tailpieces at the $C$-termini of the heavy chains are also glycosylated. IgAl has an extended, glycosylated, hinge region which is absent from the IgA2 allotypes. Heavy chains can be linked by disulphide bonds between $\mathrm{C}_{\mathrm{H}} 2$ domains, $\mathrm{C}_{\mathrm{H}} 3$ domains and between cysteines at the hinge $/ \mathrm{C}_{\mathrm{H}} 2$ boundary. In $\operatorname{IgA} 2 \mathrm{~m}(1)$ the terminal cysteines of each light chain (hatched) are disulphide bonded, whereas in $\operatorname{IgA} 1$ and $\operatorname{IgA} 2 \mathrm{~m}(2)$ they are linked to cysteines in the $\mathrm{V}_{\mathrm{H}} / \mathrm{C}_{\mathrm{H}} 1$ boundary.

are thought to be important in the pathogenicity of the bacteria. The allotypic variants of $\operatorname{IgA} 2, \operatorname{IgA} 2 \mathrm{~m}(1)$ and $\operatorname{IgA} 2 \mathrm{~m}(2)$, differ in important respects [37]. A2m(1) molecules lack the disulphide bond between the heavy and light chains, allowing the two light chains to be linked to each other. Under denaturing conditions, the molecule therefore splits into heavy chain and light chain dimers. The $A 2 \mathrm{~m}(2)$ allotype has the usual interchain disulphide bond. The $A 2 \mathrm{~m}(1) \alpha$ chain is a hybrid between $\mathrm{A} 1$ and $\mathrm{A} 2 \mathrm{~m}(2)$ in that the $\mathrm{C}_{\mathrm{H}} 3$ domain is identical to that in $\alpha 1$ whereas the $\mathrm{C}_{\mathrm{H}} 1$ and $\mathrm{C}_{\mathrm{H}} 2$ are identical to $\alpha 2 \mathrm{~m}(2)$. Both forms of IgA2 lack the hinge region (Fig. 2).

The amino acid sequences of human and murine $\mathbf{J}$ chain have been determined [38]. It has eight cysteine residues, six in intrachain disulphide bonds. In polymeric $\operatorname{IgA}$, two $\mathrm{J}$ chain cysteines are usually disulphide-linked to the penultimate cysteines of $\alpha$ chaips. In some IgA molecules, a second disulphide bond to a cysteine residue in the $\mathrm{C}_{\mathrm{H}} 2$ domain has been demonstrated. The exact nature of the interaction between the $\alpha$ chain and $J$ chain has not been elucidated. Although it has been shown that most molecules of secretory dimeric IgA contain one

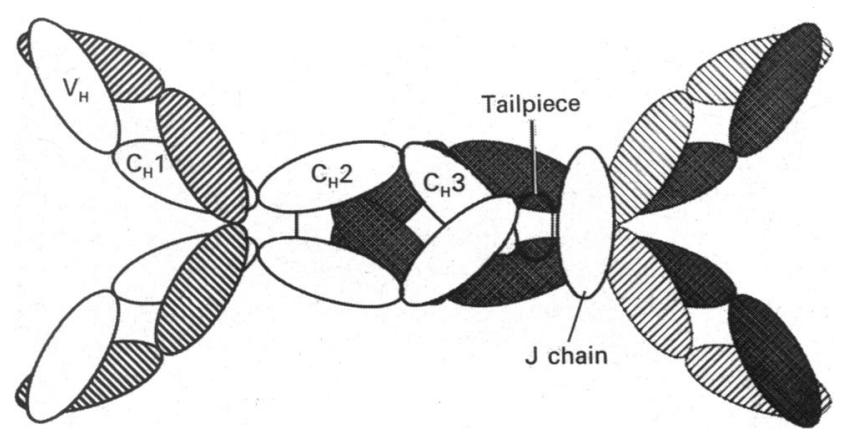

Fig. 3. Structure of dimeric IgA

This theoretical model $[5,47]$ of dimeric $\operatorname{IgA} 2 \mathrm{~m}(1)$ shows the Fc regions crossed over with $\mathrm{J}$ chain linked to the tailpiece cysteine residues of one pair of heavy chains (unhatched). These heavy chains are linked by cysteine residues in the $\mathrm{C}_{\mathrm{H}} 2$ domains to the tailpiece cysteines of the other pair of heavy chains (cross-hatched). molecule of $\mathbf{J}$ chain [39], it is not clear whether all serum dimeric IgA contains $J$ chain. Some studies [40] have shown polymeric IgA myelomas with an average of two $J$ chains per dimer, but others which lack $J$ chain have also been reported [41].

SC is produced by epithelial cells lining the mucosal surface, unlike the IgA and $J$ chain which are synthesized in mucosal lymphocytes. SC is found in secretions complexed to $\operatorname{IgA}$ (or IgM) and also as a free glycoprotein. It has been shown to stabilize markedly the structure of secretory $\operatorname{IgA}$ and to increase its resistance to proteolysis [42]. SC is somewhat heterogeneous, with molecular masses reported from 50 to $90 \mathrm{kDa}$. It is heavily glycosylated with $N$-linked sugars. The amino acid sequence of SC from rabbit and human has been determined [43, 44]. Human SC contains 20 cysteine residues. Although it confers marked stability to secretory $\operatorname{IgA}$, in its free form, it is remarkably susceptible to proteolysis.

The detail of the interaction between $\mathrm{SC}$ and $\operatorname{IgA}$ remains controversial. Most of the secretory $\operatorname{IgA}$ contains two IgA monomers, one $\mathrm{J}$ chain and one SC which are covalently linked to the $\alpha$ chains. The antigenic determinants of $\mathbf{J}$ chain appear to

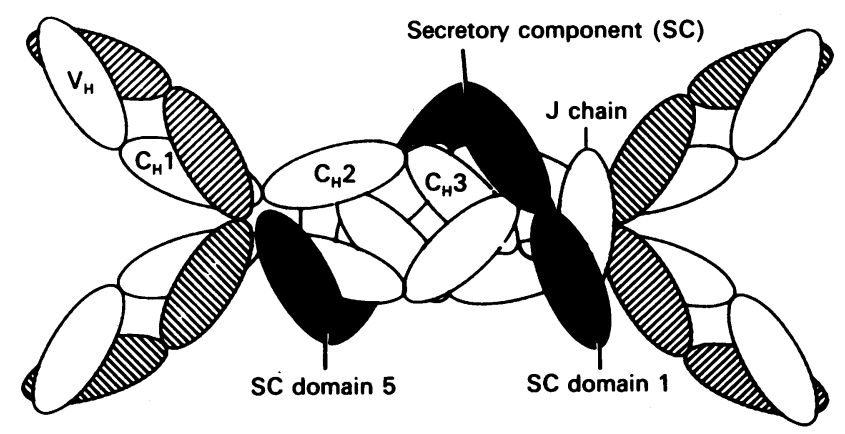

Fig. 4. Structure of secretory IgA

This theoretical model of secretory $\operatorname{IgA} 2 \mathrm{~m}(1)$ shows secretory component (dark shading) interacting with $\mathrm{C}_{\mathrm{H}} 2$ and $\mathrm{C}_{\mathrm{H}} 3$ domains of both pairs of heavy chains. The fifth domain of the secretory component is disulphide-linked to the $\mathrm{C}_{\mathrm{H}} 2$ domain of one of the IgA monomers. 
be buried within the structure, and since SC does not bind to monomeric IgA it appears that $\mathrm{J}$ chain is involved in the binding. The affinity of SC for polymeric IgA is rather high $\left(K_{\mathrm{a}} 10^{8} \mathrm{M}^{-1}\right)$. SC is linked by disulphide bonds to the $\alpha$ chain, probably to Cys299 and/or Cys-301 of the $\mathrm{C}_{\mathrm{H}} 2$ domain [32]. Immunochemical studies [45] have suggested that both the $\mathrm{C}_{\mathrm{H}} 2$ and $\mathrm{C}_{\mathrm{H}} 3$ domains of the IgA are equally and independently involved in the interaction with SC (Fig. 4). However, IgA proteases cleaving at the hinge region or between the $\mathrm{C}_{\mathrm{H}} 2$ and $\mathrm{C}_{\mathrm{H}} 3$ domains will cleave secretory $\operatorname{IgA}$, albeit slower than serum $\operatorname{IgA}[37,46]$. Several different $\operatorname{IgA} \mathrm{Fc}$ receptors will also bind to both monomeric and secretory forms of IgA. Taken together, these results suggest that, contrary to some earlier models (47) of the structure of secretory $\mathrm{IgA}$, much of the $\mathrm{Fc}$ region might be exposed.

\section{THE GLYCOSYLATION OF IgA}

IgAl contains two potential $N$-linked glycosylation sites and five $O$-linked sites in the hinge region. IgA2 lacks these $O$-linked sugars, but $\operatorname{IgA} 2 \mathrm{~m}(1)$ has two extra $N$-linked sites, one each in the $\mathrm{C}_{\mathrm{H}} 1$ and $\mathrm{C}_{\mathrm{H}} 2$ domains. The $\mathrm{A} 2 \mathrm{~m}(2)$ allotype has a further potential $N$-linked site in the $\mathrm{C}_{\mathrm{H}} 1$ domain. The $O$-linked sugars found in a serum myeloma IgA 1 are simple, one site having only $N$-acetylgalactosamine and four others having galactosyl- $(\beta 1-3)$ $N$-acetylgalactosamine residues [48]. The $O$-linked sugars isolated from milk sIgA appear to be more complex and heterogeneous, containing sialic acid, fucose and $N$-acetylglucosamine $[49,50]$. The $N$-linked sugars of serum and secretory IgA are complex and variable in structure [51]. Both $\mathbf{J}$ chain and $\mathrm{SC}$ are also glycosylated, $\mathrm{J}$ chain ( $8 \%$ carbohydrate) with a single $N$-linked chain, SC ( $22 \%$ carbohydrate) with five to seven chains, making sIgA a relatively heavily glycosylated molecule. It is generally accepted that SC confers marked stability on the SIgA and this might be due to the carbohydrate. It has been proposed that mannose-specific bacterial adhesins might interact with IgA2, both serum and secretory, through these $N$-linked sugars [52]. The interaction of the asialoglycoprotein receptor with the carbohydrate chains of IgA will be discussed later.

The purification of $\operatorname{IgA}$ and separation of $\operatorname{IgA} 1$ and $\operatorname{IgA} 2$ have been greatly facilitated by the availability of a lectin, jacalin, purified from the seed of the jackfruit (Atrocarpus spp.), which has specificity for galactose residues such as those on the hinge region of IgA1 [53]. Jacalin binds to serum or SIgA1 but does not recognize IgG, IgM or IgA2 of either allotype [54, 55]. The lectin has been used extensively for the affinity purification of IgA1, although care must be taken since there does appear to be heterogeneity in the jacalin preparations from different sources, some binding only to serum and sIgAl whilst others show weaker but significant binding to IgA2 [56-58]. Jacalin does not bind to mouse, rat, pig, goat, horse, cow or $\operatorname{dog} \operatorname{IgA}[59,60]$. Although the lectin is of considerable value in the purification of human IgAl it is not totally specific, recognizing other serum and also cell-surface proteins. The interaction with IgA is unaffected by bivalent metal ions or by many detergents, although it is inhibited by denaturing agents. Jacalin has an apparent molecular mass of $40-50 \mathrm{kDa}$ and is a tetramer comprised of two distinct types of polypeptide chain [61,62]. Since serum and sIgA1 bind with similar affinity it appears that the hinge region of IgA1 is readily accessible in both species.

\section{THE SECRETION OF IgA AND THE ROLE OF THE POLY(Ig) RECEPTOR}

Most $\operatorname{IgA}$ is produced by mucosal lymphocytes as $\mathrm{J}$-chainassociated dimers. These dimers are bound rapidly by a polymeric-immunoglobulin receptor present on the surface of epithelial cells lining the mucosal surfaces. This poly(Ig) receptor, which has a molecular mass of $100 \mathrm{kDa}$, is the precursor of SC. It is a member of the immunoglobulin superfamily, comprising five immunoglobulin-like domains, a 23-amino-acid membranespanning region and a 103-amino-acid cytosplasmic tail [44]. After synthesis, the receptor is specifically directed to the basolateral membrane of the epithelial cells. Here, the receptor binds polymeric $\operatorname{IgA}$ with high affinity and transcytoses the ligand to the luminal surface where it is cleaved by one or more proteinases to release the IgA with associated SC. The remaining membrane-bound $20 \mathrm{kDa}$ fragment is further degraded intracellularily. Transcytosis of the receptor, which does not depend on ligand binding, occurs with a $t_{\frac{1}{2}}$ of $30 \mathrm{~min}$ [63]. Unbound receptor appears to be cleaved to release free $\mathrm{SC}$ found in secretions. The transcytosis in specific vesicles has been studied extensively and reviewed recently $[5,64]$.

Study of rabbit SC, which is highly heterogeneous in terms of molecular mass and glycosylation, has suggested that the first $\mathrm{N}$-terminal domain of SC is necessary and sufficient for efficient non-covalent binding to dimeric IgA [65]. Immunochemical studies using a large panel of monoclonal antibodies against human SC showed that most SC-related epitopes on SIgA appear to be generated by the physical interaction of $\mathrm{SC}$ with dimeric IgA, whereas most epitopes on free $\mathrm{SC}$ are masked or altered by this interaction [66]. These results are consistent with the marked decrease in sensitivity of the SC to proteases which occurs on binding to IgA, suggesting marked changes in the conformation of the receptor after binding.

In rodents the poly $(\mathrm{Ig})$ receptor is expressed on the sinusoidal surface of hepatocytes and the liver plays a key role in the translocation of IgA into the upper gastrointestinal tract $[5,64]$. Polymeric forms of IgA are efficiently transported from the circulation into the bile, possibly transporting IgA-bound antigens at the same time. In man and in some other animals this mechanism does not appear to function $[67,68]$, although it has recently been shown that human hepatocytes do express some poly(Ig) receptor [69]. It is well established that the liver does play an important role in the IgA system even in man. Liver disease is frequently associated with marked elevations in the serum IgA levels and in increased serum polymeric IgA [70]. Although human biliary epithelial cells do express the receptor which can effect limited secretion of pIgA into bile, most of the biliary pIgA is synthesized locally in biliary tract plasma cells [71].

IgA interactions with hepatocytes can also be mediated by the asialoglycoprotein receptor or hepatic binding protein [72]. This lectin, which recognizes the $O$-linked sugars of $\operatorname{IgA}$ and other proteins after desialylation, is found on the hepatocytes of most animals including man. In rodents, both the poly(Ig) receptor and the asialoglycoprotein receptor can bind polymeric serum IgA. Whereas polymeric mouse IgA is taken up via the poly(Ig) receptor (SC), for quantitative delivery to bile, when polymeric human IgA is presented as a ligand in the rat, it is recognized both by secretory component and by the asialoglycoprotein receptor, possibly being first captured from blood by the asialoglycoprotein receptor and then switching to the poly(Ig) receptor during transport, implying that the two receptors briefly share a common intracellular compartment. Apart from this early compartment, there is remarkable selectivity in the intracellular traffic of these vesicles since IgA bound to the asialoglycoprotein receptor in the same cells is transported not to the luminal surface but to an intracellular compartment where it is degraded in lysosomes [73]. The role of this hepatic lectin in man remains to be clarified, although it is well documented that it can bind both serum and secretory IgA1 [74, 75,]. 


\section{BINDING OF IgA TO SERUM AND SECRETED PROTEINS}

The penultimate cysteine residue at the $C$-terminus of monomeric serum $\operatorname{IgA}$ is available for complexing with other serum proteins with a similar free SH- group. Amongst the proteins which have been shown to be complexed in this way are albumin, $\alpha_{1}$-proteinase inhibitor ( $\alpha_{1}$-antitrypsin) and the heterogeneously charged (HC)-protein, which is related to $\alpha_{1}$ microglobulin. These complexes appear to be a common component of IgA myeloma sera [76] although their significance is not known. Complexes of $\alpha_{1}$-proteinase inhibitor and $\operatorname{IgA}$ of all classes have been found in myeloma sera [77, 78]. Since $\alpha_{1}$ antiproteinase is a potent inhibitor of leucocyte elastase and thus an important regulator of inflammation, it is interesting that the IgA-inhibitor complex has also been detected in the sera of patients with rheumatoid arthritis [79].

HC-protein is a heterogeneously charged low-molecular-mass protein of unknown function first isolated from human urine. It is found in serum at aroung $40 \mathrm{mg} / 1$, half of which is complexed with IgA [80]. The low-molecular-mass form in serum appears to be identical in amino acid sequence to the urinary protein, although its charge heterogeneity is less pronounced. The HC protein is not found in IgA-deficient plasma nor is it found associated with other proteins in normal or myeloma sera. It appears to be associated almost exclusively with monomeric $\operatorname{IgA}$, even in plasma containing predominantly dimeric IgA myelomas $[81,82]$. On SDS gels the plasma high-molecular-mass protein HC appears to be made up of four polypeptide chains: two light immunoglobulin chains, one IgA $\alpha$ chain, and one chain with of approx. $90 \mathrm{kDa}$ having both $\alpha$-chain and protein $\mathrm{HC}$ antigenic determinants, although some reports suggest the $90 \mathrm{kDa}$ component to lack IgA epitopes.

Both HC-protein and its IgA complex are inhibitors of the directed (chemotactic) but not the random migration of neutrophils [83]. Concentrations of HC-protein and its IgA complex producing significant inhibition of the chemotaxis are found to occur in plasma from healthy and diseased individuals as well as in synovial fluid from patients with rheumatoid arthritis, suggesting that HC-protein and its IgA complex play physiological roles in the regulation of the inflammatory response. In addition to these serum proteins shown to bind to the free SH group of monomeric IgA, a recent report [84] suggests an association between fibronectin and $\operatorname{IgA}$ in patients with primary $\operatorname{IgA}$ nephropathy. Complexes are able to bind collagens I, II, and IV through the collagen-binding site of the fibronectin. In colostrum and milk, the bacteriostatic effect of sIgA in vitro has been shown to be increased in the presence of the iron-binding proteins lactoferrin and transferrin $[85,86]$, some of the lactoferrin being covalently bound to $\operatorname{sIgA}[87]$.

\section{BACTERIAL IgA RECEPTORS AND PROTEIN A}

Since $\operatorname{IgA}$ is the major immunoglobulin at mucosal surfaces, it is not unexpected that pathogenic bacteria have evolved mechanisms by which to evade the effects of these antibodies. One mechanism utilized by some streptococci involves a cellsurface receptor which recognizes the $\mathrm{Fc}$ region of $\operatorname{IgA}$. This receptor, found on group $A$ strains of certain $M$ types, plays an important role as a virulence factor for these micro-organisms because of its anti-phagocytic activity $[88,89]$. The IgA receptor is found together with IgG receptors on some strains but others express only receptors for IgA. In group B strains of various serotypes, the receptor is a $130 \mathrm{kDa}$ detergent-extractable protein which recognizes monomeric or polymeric IgA but not IgM or IgG [90]. IgA receptors from several group A strains have been purified and cloned [91, 92]. They are similar but not identical. The gene coding for the receptor is closely linked to that of the fibrinogen receptor, which is probably an $\mathbf{M}$ protein.

Protein A, the classical IgG-binding protein of staphylococci, has also been shown to bind to some IgA molecules. Although first reports [93] suggested that human colostral $\operatorname{IgA}$ and $\operatorname{IgA}$ myelomas could be separated into Protein A reactive and nonreactive forms, possibly corresponding to $\operatorname{IgA} 2$ and $\operatorname{IgA} 1$, subsequent work [94] suggested that this was an oversimplification with different IgAl myelomas binding to different extents from $1 \%$ to $84 \%$. Binding appears to be generally greater with predominantly polymeric myelomas and the binding site resides in the Fab region, probably in the $\mathrm{C}_{\mathrm{H}} 1$ domain. In contrast to IgG, the Fc region does not contain a binding site [95]. The significance of this binding in vivo has not been studied.

\section{BACTERIAL IgA PROTEINASES}

Another method of evasion of the immune system is the secretion by a limited number of highly pathogenic bacteria of proteinases with marked specificity for $\operatorname{IgA1}$. These bacteria include important pathogens of mucosal surfaces such as Neisseria gonorrhoeae, $N$. meningitidis, Haemophilus influenzae and Streptococcus pneumoniae. Since other related, but nonpathogenic, species of the same bacterial genera do not produce IgA proteinases, the production of these enzymes may be associated with the virulence of the organisms $[96,97]$. The IgA proteinases produced by these bacteria are characterized by their extremely narrow substrate specificity, being able to cleave only IgAl from humans, some apes and gorillas. The enzymes cleave the heavy chain of IgA1 at Pro-Ser or Pro-Thr bonds within the hinge region to yield intact $\mathrm{Fab}$ and $\mathrm{Fc}$ fragments. This segment is not present in IgA2, which is thereby resistant (Scheme 1).

Although inhibitor studies suggest these IgA proteinases to be metalloenzymes, gene cloning has shown them to be highly

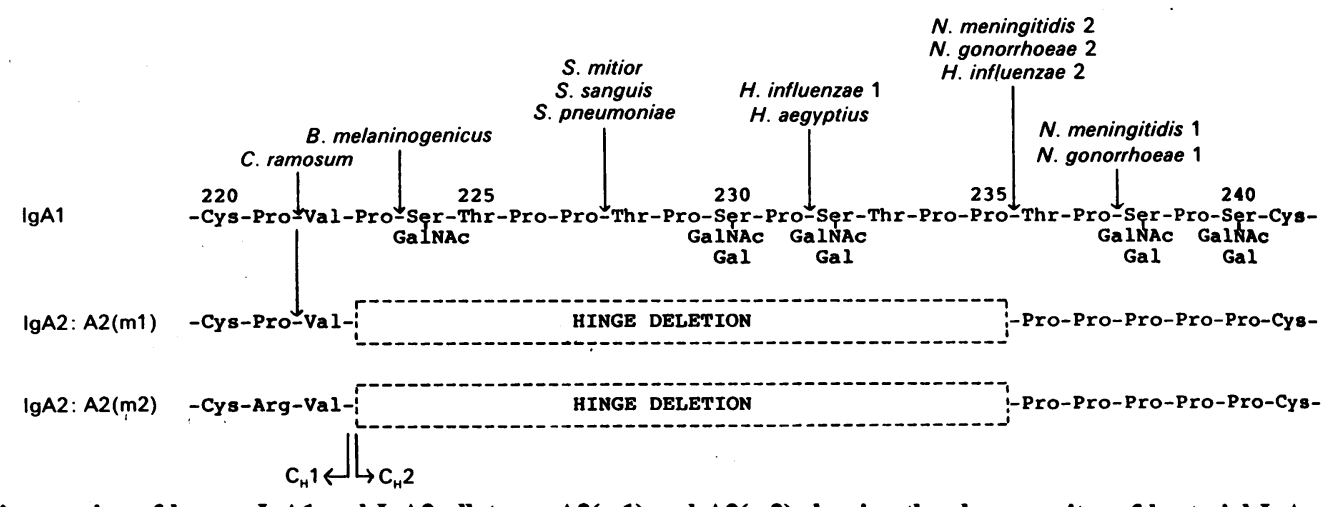

Scheme 1. The hinge region of human IgA1 and IgA2 allotypes A2(m1) and A2(m2) showing the cleavage sites of bacterial IgA proteinases 
complex and unusual bacterial proteinases. Sequencing of the gene for the IgA proteinase from $N$. gonorrhoeae shows the secreted form of the enzyme to be a $105 \mathrm{kDa}$ protein derived from a $169 \mathrm{kDa}$ precursor molecule by autoproteolytic cleavage at sites in the precursor which are similar to the target site in IgA1. Since consensus sequences of the specific cleavage sites are found in a number of relevant human proteins, the proteinase may have other natural substrates besides $\operatorname{IgAl}[98,99]$.

Different strains of $\boldsymbol{H}$. influenzae produce three distinct types of $\operatorname{IgA}$ proteinases that cleave different peptide bonds within the IgA1 hinge region. Most serotypes have a single gene except for serotype $f$ strains which produce two proteinases. There appears to be considerable homology between the proteinase genes of the various serotypes. Interestingly, three strains without detectable IgA1 protease activity appear to have proteinase genes [100, 101]. Cloning of the gene from serotype $b$ shows that the enzyme also has strong homology with the proteinase from $N$. gonorrhoeae, both having precursors which undergo similar processing on secretion [102]. The gene for the IgA proteinase from the oral bacterium, Streptococcus sanguis, has also been cloned [103]. It does not hybridize with chromosomal DNA of gram-negative bacteria that excrete IgA proteinase or $S$. pneumoniae, although the IgA proteinases of these two streptococcal species cleave the identical peptide bond in the human $\operatorname{IgAl}$ heavy-chain hinge region.

In addition to these classical IgA proteinases, a number of other species have been shown to secrete proteinases which cleave IgA. Some of these enzymes have the characteristic limited specificity, whilst others have broader specificity. A survey of gram-negative bacteria isolated from patients with urinary tract infections showed many (seven genera, eight species) to hydrolyse myeloma IgA but not IgG, IgM or secretory IgA [104]. Some of the proteinases responsible for this hydrolysis were dissimilar in the specificity of their $\operatorname{IgA}$ cleavage sites. We have shown that many species of Proteus, a common pathogen of the urinary tract, produce an EDTA-sensitive proteinase which cleaves secretory and serum $\operatorname{IgA} 1$ and $\operatorname{IgA} 2$ outside the hinge region [105]. The purified $50 \mathrm{kDa}$ enzyme has rather broad substrate specificity, cleaving not only the two isotypes of $\operatorname{IgA}$ but also IgG and a limited number of non-immunoglobulin proteins such as secretory component, casein and bovine serum albumin [46].

Only one other IgA proteinase has been shown to cleave both IgA1 and $\operatorname{IgA} 2$ selectively. This is secreted by a strain of Clostridium ramosum associated with ulcerative colitis [106]. This enzyme cleaves a Pro-Val bond found just before the hinge region in the $\alpha$ chains of $\operatorname{IgA} 1$ and the $\operatorname{IgA} 2 \mathrm{~m}(1)$ allotype, but not in $\operatorname{IgA} 2 \mathrm{~m}(2)$ where it is Arg-Val. The proteinase, like most $\operatorname{IgA}$ proteinases, is sensitive to EDTA [107]. Other bacterial pathogens shown to produce proteolytic enzymes capable of degrading IgG as well as IgA include some species of the periodontal pathogens Bacteriodes and Capnocytophaga [108, 109]. However, many of these species degrade $\operatorname{IgA} 1, \operatorname{IgA} 2$ and IgG extensively, yielding fragments too small to be detectable by electrophoresis.

It is interesting that these proteinases are resistant to plasma proteinase inhibitors such as $\alpha_{1}$-proteinase inhibitor and even $\alpha_{2}$-macroglobulin [110]. However, it appears that the enzymes produced by $H$. influenzae, $S$. pneumoniae, $N$. gonorrhoeae and $N$. meningitidis, but not by $C$. ramosum, can be inactivated by specific enzyme-neutralizing antibodies present in serum or $\operatorname{sIgA}$ preparations [111]. Although the pathological significance of these proteinases has not been firmly established, it is remarkable that the three major causes of meningitis all secrete $\operatorname{IgA}$ proteinases [96]. The presence of $\mathrm{Fab}$ and $\mathrm{Fc}$ fragments and detectable IgA proteinase activity in secretions of patients infected with IgA-proteinase-producing bacteria suggests that these proteinases are produced and are active in vivo. These enzymes are valuable tools for the biochemist seeking to correlate the inadequately defined functions of $\operatorname{IgA}$ with its structure.

\section{THE INTERACTION OF IgA WITH COMPLEMENT}

The activation of complement by $\operatorname{IgA}$ remains a confusing and controversial subject. Compared with IgM and IgG, IgA is a poor activator of complement. However, there is important debate about how (in)efficiently IgA activates complement, with contradictory evidence resulting from the use of different assays and different sources of $\operatorname{IgA}$ and complement. Assays which use IgA antibodies recognizing erythrocyte antigens or antigens absorbed onto erythrocytes have generally produced negative results, suggesting that $\operatorname{IgA}$-dependent complement-mediated cytolysis or microbial killing is of limited immunological importance. The activation of complement by immune complexes is of greater significance when considering the pathogenesis of diseases associated with $\operatorname{IgA}$ immune complexes. It is well established that a major function of the complement system is the maintenance in solution of immune complexes or antibodyantigen aggregates. If IgA-containing complexes do not activate complement then these complexes could become insoluble and thus have considerable pathogenic potential.

There is general agreement that aggregated $\operatorname{IgA}$ or $\operatorname{IgA}$ antibody-antigen aggregates do not activate the classical pathway. The Fc fragments of some myeloma IgAs appear to activate through $\mathrm{Cl}$ even though the intact myelomas do not [112]. Several reports have shown that IgA antibodies will inhibit the activation of the classical pathway by IgG or IgM antibodies recognizing the same antigen $[13,113]$. This has been interpreted to suggest that serum IgA might limit the activation of complement by bacteria entering the circulation from mucosal sites and therefore direct the micro-organisms into macrophages and away from polymorphonuclear leukocytes, allowing removal and processing of antigen whilst limiting the inflammatory response [114]. A recent report [115] from the same laboratory, which shows that specific human IgA1 antibodies are able to kill $N$. meningitidis through activation of the classical pathway, suggests that further work is needed in this area.

There is evidence from several laboratories that the alternative pathway of a number of species is activated by aggregated IgA. This observation, first reported in 1971 [116] means that the significance of the inhibitory effects of IgA must be interpreted with caution since these experiments were usually carried out at low serum concentration where activation of the alternative pathway is not achieved. More recent studies [16] have shown both subclasses of serum and secretory $\operatorname{IgA}$ to activate the alternative pathway when bound to glutaraldehyde-coated microtitre plates. Activation also occurred with $\mathrm{F}\left(\mathrm{ab}^{\prime}\right)_{2}$ and $\mathrm{F}(\mathrm{abc})_{2}$ but not Fab or Fc fragments, indicating the need for aggregation of the Fab region but not the presence of the hinge or Fc region. The significance of these results has, however, been questioned by a second study which showed that although IgA antibodies bound directly to plastic could activate the alternative pathway, when bound through antigen they could not [117].

Activation of the alternative pathway of human complement has also been demonstrated by the lysis of erythrocytes coated with a monoclonal mouse IgG1 against $\operatorname{IgA}$ when incubated with human serum in the presence of aggregated human IgA [118]. The activation of complement by IgA from other species has been studied in more detail and shown to be a complex issue dependent on the system used, the state of aggregation of the $\operatorname{IgA}$ and the source of complement. Some of these studies are summarised in Table 2 . The results suggest that the alternative pathway is less easily activated in human serum than in most other species. 
Table 2. Activation of complement by IgA

Abbreviations used: HS, GPS, MS, RS, human, guinea pig, mouse or rat serum; CP, classical pathway; AP, alternative pathway; RBC, red blood cell; TNP, trinitrophenyl; DNP, dinitrophenyl; BSA, bovine serum albumin; PC, phosphorylcholine; KLH, keyhole limpet haemocyanin.

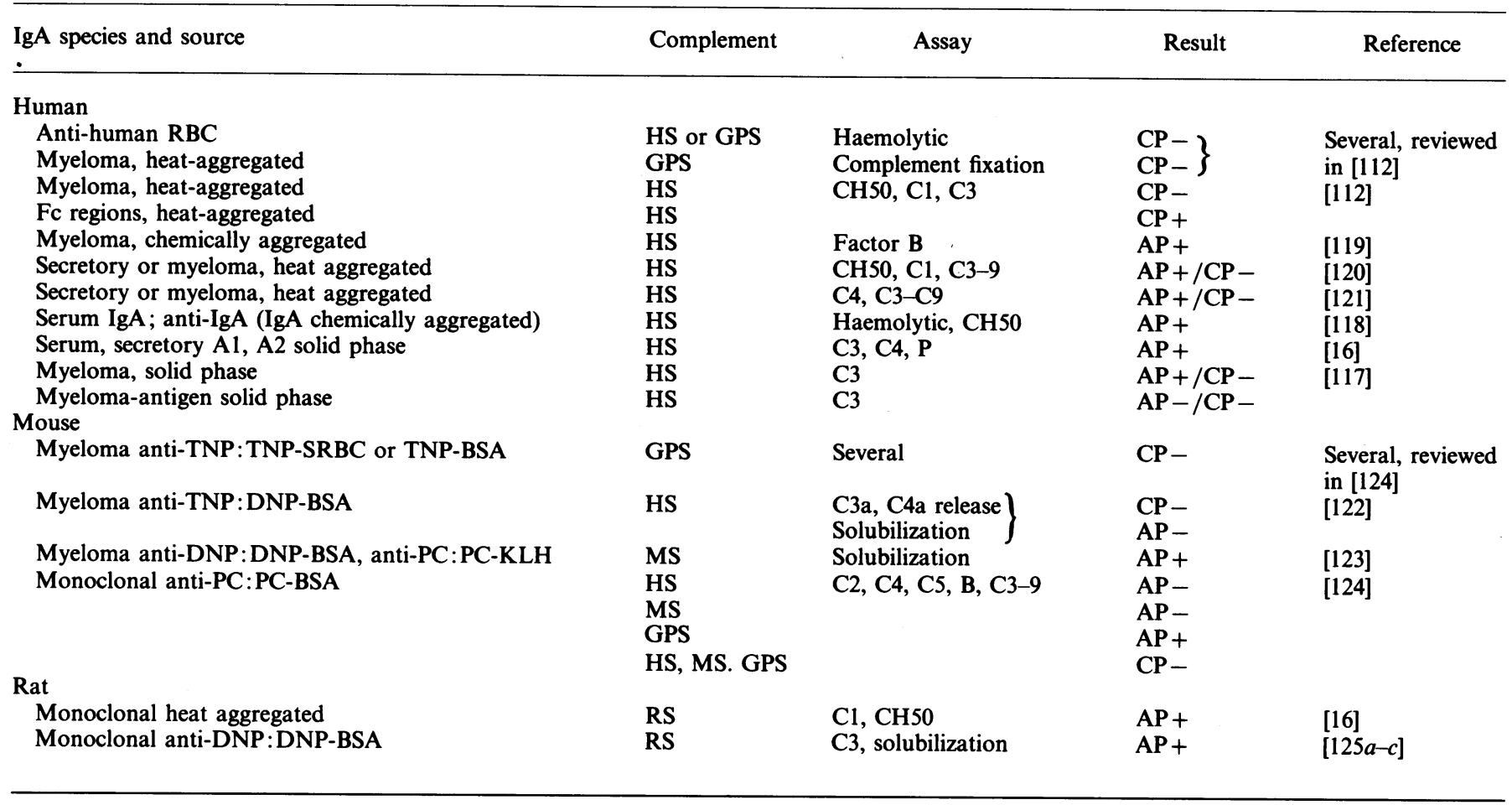

IgA nephropathy is one of the commonest causes of kidney disease, and appears to be the result of a buildup of $\operatorname{IgA}$ containing immune complexes in the kidney. Extensive study of this disease has led to important insights into the role of complement in the interaction of $\operatorname{IgA}$-containing complexes. The sera of patients with IgA nephropathy and other IgA immune complex-associated diseases frequently contain IgA 'immune complexes' detectable by the complement (C3)-dependent assays [126]. Although some reports suggest these complexes to be small, other studies [127] have shown the complexes to contain IgA, IgG, and C3 with $\mathrm{C} 3$ fragments associated only with the IgG.

Rifai and colleagues have shown that heat-aggregated human $\operatorname{IgG}$, but not $\operatorname{IgA}$, mixed with normal human serum causes $\mathrm{C} 3$ activation. In mixed aggregates, there was a linear decrease in $\mathrm{C} 3$ activation as the percentage of $\operatorname{IgA}$ increased. When naturally occurring human IgA immune complexes and covalently crosslinked human IgA oligomers were added to fresh normal human serum both failed to activate complement [128]. Furthermore, the same aggregates upon injection into mice resulted in intense glomerular deposition of IgA but no C3. Collectively, these findings suggest that neither soluble nor renal-localized human IgA complexes activate complement. However, the same authors subsequently [129] showed that large chemically cross-linked IgA oligomers prepared with purified $\operatorname{IgA}$ of different specificity, when injected simultaneously with antigen, deposited to a similar amount in glomeruli but had markedly different amounts of $\mathrm{C} 3$ associated. These results suggest that the activation of complement by $\operatorname{IgA}$ immune complexes can be highly dependent on the nature of the antigen and on the presence of IgG in the complex.

\section{IgA RECEPTORS ON HUMAN GRANULOCYTES}

Although IgG Fc receptors on phagocytic cells and other leucocytes have been extensively studied in recent years [130], IgA receptors (IgA-R) have received relatively little attention. Nevertheless, the direct binding of $\operatorname{IgA}$ to human neutrophils, monocytes and macrophages has been clearly demonstrated by several techniques. A recent report suggests the presence of an IgA receptor on eosinophils [131]. A large number of studies have shown aggregated $\operatorname{IgA}$ to stimulate or inhibit a variety of neutrophil functions. The neutrophil receptor was first demonstrated by Fanger and colleagues by using rosetting techniques $[132,133]$. They also showed that the expression of the receptor on blood neutrophils was apparently enhanced by overnight incubation with IgA. Oral neutrophils expressed more receptors per cell than neutrophils in blood and were capable of phagocytosing target cells coated with IgA alone. In functional studies, IgA-R appeared to co-operate with receptors for IgG in enhancing the phagocytosis of target cells coated with IgG and $\operatorname{IgA}$.

Other studies have also shown that the expression of these receptors can be controlled by external factors. GM-CSF and GCSF, but not IL-3, have been shown to induce a change from low- to high-affinity neutrophil IgA-R receptors within $30 \mathrm{~min}$, a change which is associated with the development of IgA-mediated phagocytosis [134]. The human promyelocytic leukaemia cell line HL-60, which does not express IgA-R, can be induced to do so by treatment of with the differentiating agent calcitriol. Again, these cells are capable of ingesting IgA-coated erythrocyte targets [135].

Several early studies, using mainly animal serum $\operatorname{IgA}$, human myeloma IgA or human colostral secretory $\operatorname{IgA}$, showed that $\operatorname{IgA}$ did not opsonise erythrocytes [136, 137], cells or micro-organisms [138-140] for phagocytosis by human neutrophils. Other studies [14] suggested that normal serum and sIgA could inhibit the binding and phagocytosis of yeast. This inhibition, which was enhanced by heat aggregation of the $\operatorname{IgA}$, was apparently due to the binding of the IgA to the neutrophil. Aggregated IgA has also 
been shown to inhibit other neutrophil functions. An inhibitor of neutrophil chemotaxis found in the serum of patients with liver disease or IgA nephropathy has been identified as polymeric IgA $[15,141,142]$.

Human IgA myeloma proteins have been shown to inhibit the chemotaxis and chemotactic peptide-induced chemiluminescence of neutrophils [143]. This inhibition is mediated by the Fc part of the molecule and potentiated by heating and aggregation. The binding and phagocytosis of aggregated $\operatorname{IgA}$ has been demonstrated in several laboratories $[144,145]$, both in vitro where the rate of uptake of aggregated IgA myeloma proteins and subsequent release of granule enzymes is similar to that of IgG aggregates, and in vivo where IgA immune complexes have been detected in neutrophils isolated from patients with IgA nephropathy $[146,147]$.

We have studied the interaction of serum IgA with neutrophils using several different systems. Whilst investigating the ability of pathological sera to opsonise yeast we identified a heat-stable opsonic activity in the sera of patients with liver and inflammatory bowel disease which was due to IgA anti-(yeast mannan) antibody [17]. Using an assay for yeast phagocytosis in which both yeast and neutrophils are kept in suspension, $\operatorname{IgA}$ showed greater opsonic activity than IgG anti-mannan antibody. If yeast and neutrophils were allowed to settle, $\operatorname{IgA}$ and $\operatorname{IgG}$ were equally efficient opsonins. IgA antibodies are at least as efficient as IgG in causing the degranulation of neutrophils as measured by enzyme release or by triggering of the respiratory burst. Similar effects have also been observed for IgA-opsonized $S$. aureus [18].

Neutrophils will bind to IgA-Sepharose or IgG-Sepharose, but not to BSA-Sepharose, and this binding elicits a similar respiratory burst and degranulation response. We have used IgA-Sepharose to purify the IgA-R from human neutrophils by affinity chromatography of detergent-solubilized membrane extracts [148]. The receptor, identified initially from radiolabelled cell membrane proteins, but more recently by silver staining of the purified protein, appeared on SDS gels as a diffuse band corresponding to a protein of $M_{\mathrm{r}} 50-70 \mathrm{kDa}$. Using IgGSepharose under identical conditions, IgG Fc $\gamma$ RII could be isolated. When judged by the amount of radioactivity or protein recovered, the amount of $\operatorname{IgA-R}$ purified was similar to that of the FcR $\gamma$ II receptor. The amount of IgA-R recovered was less than the amount of FcR $\gamma$ III which could be precipitated from the same neutrophil extract using CD16 monoclonal antibodies. Since in our experiments the low affinity of the FcR $\gamma$ III receptor prevented purification on the IgG-Sepharose resin, it appeared that the affinity of $\operatorname{IgA}-\mathrm{R}$ for $\operatorname{IgA}$ must be similar to that of FcR $\gamma$ II for IgG.

After elution from the $\operatorname{IgA}$-Sepharose affinity columns with $0.5 \mathrm{M}$-acetic acid, upon neutralization $\operatorname{IgA}-\mathrm{R}$ rebound specifically to IgA- but not to IgG- or BSA-Sepharose. The binding of receptor to $\operatorname{IgA}$-Sepharose was blocked by $\operatorname{IgA} 1$ or $\operatorname{IgA} 2$ in both monomeric and secretory forms but not by $\operatorname{IgG}$ or IgM. This confirmed, directly, earlier reports on the specificity of the receptor showing $\operatorname{IgA} 1$ and $\operatorname{IgA} 2$ to be equally efficient in their capacity to inhibit rosette formation $[145,149,150]$. Our results suggest the affinity of the receptor for $\operatorname{IgA}$ is $5 \times 10^{7} \mathrm{M}^{-1}$ [151]. We have also shown recently [151a] that when coated onto microtitre plates, serum or sIgA of either subclass or IgG are able to elicit similar levels of lucigenin-enhanced chemiluminescence from neutrophils. Although the binding site on $\operatorname{IgA}$ has not been fully determined, several studies have suggested a site on the Fc region. Since a $\operatorname{IgA}$ half-molecule lacking the $\mathrm{C}_{\mathrm{H}} 3$ domain is also recognized, it appears that it is the $\mathrm{C}_{\mathrm{H}} 2$ domain which is involved in binding to the receptor [149].

Taken together, these results demonstrate the presence on phagocytic cells of specific IgA-R with at least equal affinity and
Table 3. Comparison of the properties of neutrophil Fe receptors

Data on the IgA receptor are taken from [151, 155] where the data on IgG Fc receptors are also reviewed.

\begin{tabular}{|c|c|c|c|}
\hline & $\operatorname{Ig} A-R$ & Fc $\gamma$ RII & Fc $\gamma$ RIII \\
\hline $\begin{array}{l}\text { Molecular } \\
\text { mass (kDa) }\end{array}$ & $50-70$ & 40 & $50-70$ \\
\hline $\begin{array}{l}\text { Polypeptide } \\
\text { mass }(\mathrm{kDa})\end{array}$ & $32-36$ & $30-35$ & 30 \\
\hline $\begin{array}{l}\text { Membrane } \\
\text { linkage }\end{array}$ & Transmembrane & Transmembrane & GPI \\
\hline $\begin{array}{l}\text { Molecules } \\
\text { per cell }\end{array}$ & $10^{4}$ & $10^{4}$ & $2 \times 10^{5}$ \\
\hline Specificity & $\begin{array}{c}\operatorname{IgA} \\
\operatorname{IgA1}=\operatorname{IgA} 2 \\
=\underset{5 \times 10^{7}}{\operatorname{sIg} 1=\operatorname{sIgA} 2} \\
5 \times 10^{2}\end{array}$ & $\begin{array}{c}\text { IgG } \\
\text { IgG1 = IgG3 } \\
>\underset{\text { IgG2, IgG4 }}{<10^{6}}\end{array}$ & $\begin{array}{c}\text { IgG } \\
\text { IgG1 = IgG3 } \\
>\underset{\text { IgG2, IgG4 }}{<10^{6}}\end{array}$ \\
\hline $\begin{array}{c}\text { monomer Ig } \\
\left(\mathbf{M}^{-1}\right)\end{array}$ & & & \\
\hline
\end{tabular}

in similar amounts to the functional IgG Fc receptors (Table 3). IgA aggregated artificially or by binding to antigen will elicit similar responses to those elicited by aggregated IgG, suggesting that serum IgA might indeed play a role in defence against infection and in the generation of inflammation. These observations are not necessarily in conflict with earlier papers suggesting an inhibitory role for $\operatorname{IgA}$. The opsonic activity of $\operatorname{IgA}$ (or IgG) alone is much less than that of complement. Therefore IgG, by activating complement efficiently, will be detected in serum as a far more powerful opsonin than $\operatorname{IgA}$, which activates complement poorly. As a result, IgA antibodies competing with IgG will appear to inhibit opsonization. In the absence of complement, either as a result of depletion by immune complexes or in secretions where levels of complement are low, the importance of $\operatorname{IgA}$ as an opsonin might be increased.

\section{IgA RECEPTORS ON MONOCYTES AND MACROPHAGES}

IgA receptors have also been identified on human monocytes, macrophages and related cells by immunofluorescence and by rosetting with IgA-sensitized cells [143, 152, 153]. Peripheral blood monocytes and alveolar macrophages have been demonstrated to ingest IgA-coated particles and bacteria [154]. Recently, Monteiro et al. [155] have isolated an IgA-R from human monocytes and related cell lines which was similar to that found on neutrophils. Receptors recognizing human $\operatorname{IgA}$ have also been detected in heterologous systems using macrophages and macrophage-related cells from mouse, rat and rabbit. In mouse, a subpopulation of alveolar macrophages (around $20 \%$ ) express the receptor although this value increases along with an increase in ligand density on stimulation in vitro or in vivo [156] coincident with an increase in phagocytic activity.

The significance of IgA-R on these cells remains unclear. Ward and colleagues in a series of papers [157-159] have studied the interaction of lung macrophages and neutrophils with $\operatorname{IgA}$ and IgG immune complexes. They have shown that when IgA is instilled into the airways of rats and antigen injected intravenously, acute lung injury occurs, which is dependent on antigen and directly proportional to the amount of IgA. Lung injury related to $\operatorname{IgA}$-containing immune complexes is complement-dependent but neutrophil-independent, whereas similar lung pathology due to IgG complexes is complement- and 
neutrophil-dependent. In vitro, rat lung interstitial and alveolar macrophages incubated with IgA or IgG immune complexes produce similar amounts of superoxide in a dose-dependent manner. In contrast, peripheral blood neutrophils respond to IgG immune complexes but not to IgA immune complexes; monocytes respond to neither. The results suggest that in the rat, IgG immune complex lung injury is primarily neutrophilmediated, wheras IgA complex lung injury is predominantly macrophage-mediated.

It has been widely suggested that macrophages might also be involved in the clearance of IgA-containing immune complexes. Evidence in humans is limited but studies have been made in mice [160]. The rapid phase of removal of large IgA aggregates involves the clearance by the liver with an insignificant amount ending up in the bile. Heavy polymers of $\operatorname{dIgA}$ or mIgA predominantly localize in Kupffer cells [161, 162], a subpopulation of which express IgA-R [163]. Although these results point to a role for the reticuloendothelial system in generation of inflammation and the removal of IgA immune complexes, the mechanism remains unclear. Other studies [164] on the in vitro binding, internalization and degradation of $\operatorname{IgA}$ immune complexes (IC) by resident rat peritoneal macrophages suggest that the asialoglycoprotein receptor is involved. Although there is little information concerning the role of IgA- $R$ on mononuclear phagocytes in the killing of micro-organisms, a recent study demonstrated the phagocytosis of erythrocytes and release of superoxide triggered by IgA [165]. Human monocytes have been described to have ADCC activity $[166,167]$. Of particular significance is the observation that a human monoclonal anti-pneumococcal IgA produced from an EBVtransformed cell line induces direct killing and increases the phagocytosis of these bacteria by mouse macrophages in vitro although the antibody does not fix complement [168].

\section{IgA RECEPTORS ON LYMPHOCYTES AND THE CONTROL OF THE IgA RESPONSE}

IgA-R have been detected on subpopulations of $T$ cells, $B$ cells and also non- $T$ non-B cells of several species both in the circulation and in lymphoid tissues, especially the gut-associated lymphoid tissue [153, 169-171]. The percentage of lymphocytes expressing IgA-R is usually low but can be increased upon activation either by culturing overnight with IgA or by mitogenic stimulation in the absence of $\operatorname{IgA}$. Several reports have suggested an increase in the number of lymphocytes bearing $\operatorname{IgA}-\mathrm{R}$ in diseases associated with raised serum $\operatorname{IgA}$ or $\operatorname{IgA}$ immune complexes, such as IgA nephropathy [172] or Crohns disease [173]. IgA-R can also be induced by aggregated IgA purified from the sera of patients with IgA nephropathy [174].

Human $T$ cells increase their expression of IgA-R on stimulation with concanavalin A or phytohaemagglutinin [169, 175]. Human B cells activated with $S$. aureus, anti-IgM antibodies or $E$. coli LPS also show increased numbers of IgA-R positive cells $[175,177]$. The induction of $\operatorname{IgA}-\mathrm{R}$ expression on peripheral blood $\mathrm{T}$ cells, $\mathrm{T}$ cell lines and clones by $\operatorname{IgA}$ depends on the concentration and state of aggregation of the $\operatorname{IgA}$, with polymeric or secretory IgA being effective, but not serum IgA, IgG or IgM $[178,179]$. $T$ cell lines and $T$ cell clones derived from tonsils respond better than those established from peripheral blood. The induction of receptor expression, which is found with both $\mathrm{CD}^{+}$ and $\mathrm{CD}^{+} \mathrm{T}$ cell clones, is dependent on protein and RNA synthesis but not on DNA synthesis.

The exact function of $\operatorname{IgA}-\mathrm{R}$ on lymphocytes is not known, nor is it known whether this receptor is related to $\operatorname{IgA-R}$ on phagocytic cells. The receptors on $B$ and $T$ cells are involved in the isotype-specific immune regulation, although the mechanism remains unclear. IgA production seems to be regulated at several points during $B$ cell differentiation by IgA- $R^{+} T$ cells or products released from these cells involving the switch of isotypeuncommitted B cells as well as post-switch expansion of IgAcommitted B cells [180]. Most of the detailed functional studies on lymphocyte IgA-R have been carried out in mice [181, 182]. In one extensively studied murine system, Kiyono and colleagues [183-185] have demonstrated that IgA- $\mathrm{R}^{+}$antigen-specific $\mathrm{T}$ cell clones derived from Peyers patches are able to increase the numbers of surface $\operatorname{IgA}^{+}$but not surface $\operatorname{IgA}{ }^{-} B$ cells by release of an IgA-binding factor (IgA BF). Preincubation of $T$ helper cell clones with excess monomeric or dimeric IgA blocks the IgA response, whereas $\mathrm{F}\left(\mathrm{ab}^{\prime}\right)_{2}$ fragments of $\operatorname{IgA}$, free $\alpha$ chain and IgA molecules with $\mathrm{C}_{\mathrm{H}} 3$ deletions have no effect. The $\operatorname{IgA} \mathrm{BF}$ appears to be a soluble form of the IgA receptor since affinity chromatography of supernatants from $\operatorname{IgA}-\mathrm{R}^{+} \mathrm{T}$ cell lines results in the binding of $\operatorname{IgA}$-promoting activity to $\operatorname{IgA}$ (but not to IgM or IgG). The activity is recoverable upon elution. High concentrations of this soluble factor suppress T-dependent IgA responses, while optimal levels enhance this isotype response.

The suppression of $\operatorname{IgA}$ production by $\operatorname{IgA}-\mathrm{R}^{+}$positive cells or products derived from these cells has also been studied in several laboratories. An $\operatorname{IgA}-\mathrm{R}^{+}$murine $\mathrm{T}$ cell hybridoma stimulated with $\operatorname{IgA}$ has been shown to induce the release of $\operatorname{IgA-BF}$ which suppresses the response of mouse spleen cells in the presence of pokeweed mitogen [185]. In a human system, IgA-BF isolated from either mononuclear cell suspensions or monoclonal $\operatorname{IgA}-\mathrm{R}^{+}$ B cell lines selectively depresses the maturatton of $\mathbf{B}$ cells into $\operatorname{IgA}$ plasma cells and the proliferation of a surface $\operatorname{IgA} A^{+} \mathbf{B}$ cell line [187]. IgA- $\mathrm{R}^{+}$human $\mathrm{T}$ cells pre-incubated with aggregated IgA have been shown to selectively suppress the ability of pokeweed mitogen-stimulated B cells to produce IgA [188].

The nature of the IgA receptor and IgA-BF has been studied extensively by Yodoi and colleagues [189-194] using a murine $\mathrm{T}$ cell hybridoma, T2D4, shown to express a trypsin-sensitive receptor for IgA. The cells bind IgA in a dose-dependent manner, resulting in increased expression of $\operatorname{IgA}-\mathrm{R}$ and secretion of an IgA-BF. This factor competitively inhibits the binding of $\operatorname{IgA}$ to T2D4 cells and specifically suppresses IgA but not IgG nor IgM responses of pokeweed mitogen-stimulated spleen cells. A subpopulation of murine spleen cells activated with concanavalin A, after $18 \mathrm{~h}$ preculture with IgA, can also be induced to express $\operatorname{IgA}-\mathrm{R}$ and to release the same IgA-BF. The $\operatorname{IgA}-\mathrm{BF}$ is a $56 \mathrm{kDa}$ glycoprotein which binds to IgA-bearing but not to IgG-bearing myelomas, indicating that it interacts with B cells bearing IgA to suppress their differentiation.

A similar suppressive IgA-BF is also produced by a human natural killer (NK)-like cell line (YT), indicating these cells may also be involved in the regulation of the class-specific antibody responses and suggesting that, in human as well as murine systems, T- and NK-cells have the capacity to co-express multiple class-specific Fc receptors and to produce the corresponding immunoglobulin binding factors. Studies on an IgE-binding factor and $\mathrm{Fc}$ receptors for IgE on $\mathrm{T}$ cells have shown that both are specifically enhanced or up-regulated by IgE [194]. While the IgE receptor expression is abnormally enhanced in diseases with elevated serum $\operatorname{IgE}$, disregulation of $\operatorname{IgA}$ receptor is associated with diseases involving elevated $\operatorname{IgA}$ such as $\operatorname{IgA}$ nephropathy. Interestingly, it has recently been suggested that 'autoimmune' young NZB mice produce an IgA-BF that has aberrant biological activity when compared to $\operatorname{IgA}-\mathrm{BF}$ produced from $\operatorname{IgA}-\mathrm{R}^{+}$ $T$ cells of BALB/c mice [195]. Although the IgA receptor and binding factor have not yet been fully characterized, a recent, as yet unconfirmed, report has suggested that the murine lymphocyte IgA-R might be serologically related to secretory component [196]. 


\section{CONCLUDING REMARKS}

It is clear that $\operatorname{IgA}$ is able to bind to a variety of soluble and cell bound proteins. In many cases the full significance of these interactions has still to be elucidated. There is ample evidence that immunity to infection at mucosal surfaces is mediated by IgA. There is increasing evidence that serum IgA might also play a role in immunity although this has yet to be determined. Selective deficiency of $\operatorname{IgA}$ is one of the most frequent immunodeficiencies although these deficiencies are seldom complete [197]. This deficiency can be associated with a number of autoimmune diseases, recurrent infections and atopy, but not all deficients are symptomatic [19]. Nevertheless, there is increasing evidence that many leucocytes have receptors for $\operatorname{IgA}$ and binding of IgA to these receptors triggers a variety of effector functions. The control of mucosal IgA synthesis and secretion is complex and here again $\operatorname{IgA}$ receptors appear to play an important role.

The importance of $\operatorname{IgA}$ in the pathogenesis of certain diseases is an area of special interest. IgA-containing immune complexes are found in the serum and tissues of patients with a number of different diseases and a polyclonal increase in serum $\operatorname{IgA}$ is associated with others. Although there has been extensive research into these diseases a detailed understanding of the immunological role of $\operatorname{IgA}$ can only come from better characterization of the specific IgA receptors and elucidation of the structures of the different forms of IgA.

\section{Note added in proof}

A cDNA for a human myeloid IgA receptor has recently been isolated (C. R. Maliszewski, personal communication). The cDNA encodes a protein of approximately $30 \mathrm{kDa}$ which has six potential $\mathrm{N}$-glycosylation sites. The protein is a member of the immunoglobulin superfamily, homologous to known IgG and IgE receptors.

I thank Dr. L. Loomes, Dr. W. Stewart and R. Mazengera for helpful discussions, and Drs. Gorter and Rits, University of Leiden, for copies of their Ph.D theses. I am grateful to Mrs. H. Cowper for assistance in preparing the manuscript and Mr. C. MacLean for Figs 2-4. I acknowledge support from the Arthritis and Rheumatism Council and Biomedical Research Committee of the Scottish Home and Health Department.

\section{REFERENCES}

1. Heremans, J. F. (1974) The Antigens 2, 365-522

2. Delacroix, D. L., Dive, C., Rambaud, J. C. \& Vaerman, J. P. (1982) Immunology 47, 383-385

3. Kutteh, W. H., Prince, S. J. \& Mestecky, J. (1982) J. Immunol. 128, 990-995

4. Kett, K., Brandtzaeg, P., Radl, J. \& Haaijman, J. J. (1986) J. Immunol. 136, 3631-3635

5. Mestecky, J. \& McGhee, J. R. (1987) Adv. Immunol. 40, 153-243

6. Vaerman, J.-P. (1973) Res. Immunobiol. Immunochem. 3, 91-99

7. Czerkinsky, C., Prince, S. J., Michalek, S. M., Jackson, S., Russell, M. W., Moldoveanu, Z., McGhee, J. R. \& Mestecky, J. (1987) Proc. Natl. Acad. Sci. U.S.A. 84, 2449-2453

8. Conley, M. E. \& Delacroix, D. L. (1987) Ann. Intern. Med. 106, 892-899

9. Brown, T. A., Clements, M. L., Murphy, B. R., Radl, J., Haaijman, J. J. \& Mestecky, J. (1988) Monogr. Allergy 24, 1691-1700

10. Negro-Ponzi, A., Merlino, C., Angeretti, A. \& Penna, R. (1985) J. Clin. Microbiol. 22, 505-509

11. Brandtzaeg, P. (1985) in Mucosal Immunity, IgA and Polymorphonuclear Neutrophils, pp. 11-43, Foundation Franco-Allemande Suresnes, Paris

12. Tomasi, T. B. (1989) Immunol. Invest. 18, 1-15

13. Griffiss, J. M. \& Goroff, D. K. (1983) J. Immunol. 130, 2882-2885

14. Wilton, J. M. A. (1978) Clin. Exp. Immunol. 34, 423-428
15. Van Epps, D. E. \& Williams, R.C. (1976) J. Exp. Med. 144, 1227-1242

16. Hiemstra, P. S., Gorter, A., Stuurman, M. E., van Es, L. A. \& Daha, M. R. (1987) Eur. J. Immunol. 17, 321-326

17. Yeaman, G. R. \& Kerr, M. A. (1987) Clin. Exp. Immunol. 68, 200-208

18. Gorter, A., Hiemstra, P. S., Van der Voort, E. A. M., Van Es, L. A. \& Daha, M. R. (1988) Immunology 64, 207-212

19. Anman, A. J. \& Hong, R. (1971) Medicine 50, 223-229

20. Taylor, H. \& Dimmock, N. J. (1985) J. Exp. Med. 161, 198-20

21. Ogra, P. L., Cumella, J. C. \& Welliver, R. C. (1984) in Immunology of the Lung and Upper Respiratory Tract (Bienenstock, J., ed.), pp. 242-263, McGraw-Hill, New York

22. Leinikki, P. O., Mustonen, J. \& Pasternack, A. (1987) Clin. Exp. Immunol. 68, 33-38

23. Kalsi, J., Delacroix, D. L. \& Hodgson, H. J. F. (1983) Clin. Exp. Immunol. 52, 499-504

24. Elkon, K. B., Inman, R. D., Culhane, L. \& Christian, C. L. (1983) Am. J. Med. 75, 785-789

25. Procaccia, S., Lazzarin, A., Colucci, A., Gasparini, A., Forcellini, P., Lanzanova, D., Foppa, C. U., Novati, R. \& Zanussi, C. (1987) Clin. Exp. Immunol. 67, 236-244

26. Yagame, M., Tomino, Y., Miura, M., Tanigaki, T., Suga, T., Nomoto, Y. \& Sakai, H. (1987) Clin. Exp. Immunol. 67, 270-276

27. Bene, M. C. \& Faure, G. (1987) Springer Semin. Immunopathol. 9, 387-394

28. Svehag, S. E. \& Bloth, B. (1970) Science 168, 847-850

29. Putnam, F. W., Liu, Y. S. V. \& Low, T. L. K. (1979) J. Biol. Chem. 254, 2865-2871

30. Torano, A. \& Putnam, F. W. (1978) Proc. Natl. Acad. Sci. U.S.A. 75, 966-969

31. Tsuzukida, Y., Wang, C. C. \& Putnam, F. W. (1979) Proc. Natl. Acad. Sci. U.S.A. 76, $1104-1108$

32. Stanisz, A. M., Lieberman, R., Kaplan, A. \& Davie, J. M. (1983) Mol. Immunol. 20, 983-988

33. Knight, K. L., Martens, C. L., Stoklosa, C. M. \& Schneiderman, R. D. (1984) Nucleic Acids. Res. 12, 1657-1670

34. Burnett, R. C., Hanly, W. C., Zhai, S. K. \& Knight, K. L. (1989) EMBO J. 8, 4041-4047

35. Mestecky, J., Schrohenloher, R. E., Kulhavy, R., Wright, G. P. \& Tomana, M. (1974) Proc. Natl. Acad. Sci. U.S.A. 71, 544-548

36. Prahl, J. W., Abel, C. A. \& Grey, H. M. (1971) Biochemistry 10, 1808-1813

37. Mestecky, J. \& Kilian, M. (1985) Methods. Enzymol. 116, 37-75

38. Koshland, M. E. (1985) Annu. Rev. Immunol. 3, 425-453

39. Zikan, J., Mestecky, J., Kulhavy, R. \& Bennett, J. C. (1986) Mol. Immunol. 23, 541-544

40. Brandtzaeg, P. (1975) Scand. J. Immunol. 4, 439-450

41. Brandtzaeg, P. (1976) Scand. J. Immunol. 5, 411-419

42. Lindh, E. \& Bjork, L. (1977) Acta. Pathol. Microbiol. Scand. 15, 449-453

43. Eiffert, H., Quentin, E., Decker, J., Hillemeir, S., Hufschmidt, M., Klingmueller, D., Weber, M. H. \& Hilschmann, N. (1984) HoppeSeyler's Z. Physiol. Chem. 365, 1489-1495

44. Mostov, K. E., Friedlander, M. \& Blobel, G. (1984) Nature (London) 308, 37-43

45. Geneste, C., Iscaki, S., Mangalo, R. \& Pillot, J. (1986) Immunol. Lett. 13, 221-226

46. Loomes, L. M., Senior, B. W. \& Kerr, M. A. (1990) Infect. Immun., in the press

47. Pumphrey, R. (1986) Immunol. Today 7, 206-210

48. Baenziger, J. \& Kornfield, S. (1974) J. Biol. Chem. 249, 7270-7281

49. Pierce-Cretel, A., Debray, H., Montreuil, J., Spik, G., Van Halbeek, H., Mutsaers, J. H. G. M. \& Vliegenthart, J. F. G. (1984) Eur. J. Biochem. 139, 337-349

50. McGuire, E. J., Kerlin, R., Cebra, J. J. \& Roth, S. (1989) J. Immunol. 143, 2933-2938

51. Tomana, M., Mestecky, J. \& Niedermeier, W. (1972) J. Immunol. 108, 1631-1636

52. Wold, A. E., Mestecky, J. \& Eden, C. S. (1988) Monogr. Allergy 24, 307-309

53. Roque-Barreira, M. C. \& Campos-Neta, A. (1985) J. Immunol. 134, 1740-1743

54. Kondoh, H., Kobayashi, K., Hagiwara, K. \& Kajii, T. (1986) J. Immunol. 88, 171-173

55. Gregory, R. L., Rundegren, J. \& Arnold, R. R. (1987) J. Immunol. Methods 99, 101-106 
56. Kondoh, H., Kobayashi, K. \& Hagiwara, K. (1987) Mol. Immunol. 24, 1219-1222

57. Aucouturier, P., Mihaesco, E., Mihaesco, C. \& Preud'homme, J. (1987) Mol. Immunol. 24, 503-511

58. Aucouturier, P., Duarte, F., Mihaesco, E., Pineau, N. \& Preud'homme, J. (1988) J. Immunol. Methods 113, 185-191

59. Skea, D. L., Christopoulous, P., Plaut, A. G. \& Underdown, B. J. (1988) Mol. Immunol. 25, 1-6

60. Wilkinson, R. \& Neville, S. (1988) Vet. Immunol. Immunopathol. 18, 195-198

61. Hagiwara, K., Collet-Cassart, D., Kobayashi, K. \& Vaeman, J. (1988) Mol. Immunol. 25, 69-83

62. Mahanta, S. K., Sastry, M. V. K. \& Surolia, A. (1990) Biochem. J. 265, 831-840

63. Mostov, K. E. \& Deitcher, D. L. (1986) Cell 46, 613-621

64. Underdown, B. J. \& Schiff, J. M. (1986) Annu. Rev. Immunol. 4, 389-417

65. Woodard, C. S., Splawski, J. B., Goldblum, R. M. \& Denney, R. M. (1984) J. Immunol. 133, 2116-2125

66. Jaton, J. C., Frutiger, S. \& Hughes, G. J. (1988) Ann. Inst. Pasteur. Immunol. 139, 21-40

67. Brown, W. R. \& Kloppel, T. M. (1989) Hepatology 9, 763-784

68. Delacroix, D. L., Furtado-Barreira, G., de-Hemptinne, B., Goudswaard, J., Dive, C. \& Vaerman, J. P. (1983) Hepatology 3, 980-988

69. Perez, J. H., Wight, D. G. D., Wyatt, J. I., Van Schaik, M., Mullock, B. M. \& Luzio, J. P. (1989) Immunology 68, $474-478$

70. Delacroix, D. L., Reynaert, M., Pauwels, S., Geubel, A. P. \& Vaerman, J. P. (1982) Dig. Dis. Sci. 27, 333-340

71. Jackson, G. D. F., Walker, P. G., Schiff, J. M., Barrington, P. J., Fisher, M. M. \& Underdown, B. J. (1985) J. Immunol. 135, 152157

72. Schwartz, A. L. (1984) CRC Crit. Rev. Biochem. 16, 207-233

73. Schiff, J. M., Fisher, M. M., Jones, A. L. \& Underdown, B. J. (1986) J. Cell Biol. 102, 920-931

74. Stockert, R. J., Kressner, M. S., Collins, J. C., Sternlieb, I. \& Morell, A. G. (1982) Proc. Natl. Acad. Sci. U.S.A. 79, 6229-6231

75. Mestecky, J., Moldoveanu, Z., Tomana, M., Epps, J. M., Thorpe, S. R., Phillips, J. O. \& Kulhavy, R. (1989) Immunol. Invest. 18, 313-324

76. Tomana, M., Kulhavy, R. \& Mestecky, J. (1988) Gastroenterology 94, 762-770

77. Vaerman, J. P., Hagiwara, K., Kobayashi, K. \& Rits, M. (1987) Immunol. Lett. 15, 67-72

78. Stanworth, D. R., Lewin, I. \& Crockson, R. A. (1985) Immunol. Lett. 11, 277-280

79. Dawes, P. T., Jackson, R., Shadforth, M. F., Lewin, I. V. \& Stanworth, D. R. (1987) Br. J. Rheumatol. 26, 351-353

80. Grubb, A. O., Lopez, C., Tejler, L. \& Mendez, E. (1983) J. Biol. Chem. 258, 14698-14707

81. Cooper, E. H., Johns, E. A., Itoh, Y. \& Webb, J. R. (1985) J. Chromatogr. 327, 179-188

82. Vincent, C., Bouic, P., Revillard, J. P. \& Bataille, R. (1985) Mol. Immunol. 22, 663-673

83. Mendez, E., Fernandez-Luna, J. L., Grubb, A. \& Leyva-Cobian, F. (1986) Proc. Natl. Acad. Sci. U.S.A. 83, 1472-1475

84. Cederholm, B., Wieslander, J., Bygren, P. \& Heinegard, D. (1988) Proc. Natl. Acad. Sci. U.S.A. 85, 4865-4868

85. Funakoshi, S., Doi, T., Nakajima, T., Suyama, T. \& Tokuda, M. (1982) Microbiol. Immunol. 26, 227-239

86. Dolby, J. M. \& Stephens, S. (1983) Acta Paediatr. Scand. 72, $577-582$

87. Watanabe, T., Nagura, H., Watanabe, K. \& Brown, W. R. (1984) FEBS Lett. 168, 203-207

88. Burova, L. A., Ravdonikas, L. E., Christensen, P., Schalen, C. \& Totolian, A. A. (1983) Acta Pathol. Microbiol. Immunol. Scand. B 91, 61-67

89. Lammler, C., Frede, C. \& Blobel, G. (1988) Comp. Immunol. Microbiol. Infect. Dis. 11, 115-119

90. Russell-Jones, G. J., Gotschlich, E. C. \& Blake, M. S. (1984) J. Exp. Med. 160, 1467-1475

91. Lindahl, G. (1989) Mol. Gen. Genet. 216, 372-379

92. Lindahl, G. \& Akerstrom, B. (1989) Mol. Microbiol. 3, 239-247

93. Grov, A. (1975) Acta Pathol. Microbiol. Immunol. Scand. C 84, $71-72$

94. Biewenga, J., Daus, F., Modderman, M. L. \& Bruin, G. M. (1982) Immunol. Commun. 11, 189-200
95. Bruin, G., Faber, A. \& Biewenga, J. (1985) Scand. J. Immunol. 21, 49-54

96. Kilian, M., Mestecky, J. \& Russell, M. W. (1988) Microbiol. Rev. 52, 296-303

97. Plaut, A. G. (1983) Annu. Rev. Microbiol. 37, 603-622

98. Halter, R., Pohlner, J. \& Meyer, T. F. (1984) EMBO. J. 3, 1595-1601

99. Pohlner, J., Halter, R., Beyreuther, K. \& Meyer, T. F. (1987) Nature (London) 325, 458-462

100. Bricker, J., Mulks, M., Moxon, E. R., Plaut, A. G. \& Wright, A. (1985) Infect. Immun. 47, 370-374

101. Poulsen, K., Hjorth, J. P. \& Kilian, M. (1988) Infect. Immun. 56, 987-992

102. Poulsen, K., Brandt, J., Hjorth, J. P., Thogersen, H. C. \& Kilian; M. (1989) Infect. Immun. 57, 3097-3105

103. Gilbert, J. V., Plaut, A. G., Fishman, Y. \& Wright, A. (1988) Infect. Immun. 56, 1961-1966

104. Milazzo, F. H. \& Delisle, G. J. (1984) Infect. Immun. 43, 11-13

105. Senior, B. W., Albrechtsen, M. \& Kerr, M. A. (1987) J. Med. Microbiol. 24, 175-180

106. Fujiyama, Y., Kobayashi, K., Senda, S., Benno, Y., Bamba, T. \& Hosoda, S. (1985) J. Immunol. 134, 573-576

107. Fujiyama, Y., Iwaki, M., Hodohara, K., Hosoda, S. \& Koboyashi, K. (1986) Mol. Immunol. 23, 147-150

108. Kilian, M. (1981) Infect. Immun. 34, 757-765

109. Mortensen, S. B. \& Kilian, M. (1984) Infect. Immun. 45, 550-557

110. Gilbert, J. V., Plaut, A. G., Longmaid, B. \& Lamm, M. E. (1983) Ann. N. Y. Acad. Sci. 409, 625-636

111. Kobayashi, K., Fujiyama, Y., Hagiwara, K., Hodohara, K. \& Hosoda, S. (1987) Adv. Exp. Med. Biol. 216, 1289-1296

112. Burritt, M. F., Calvanico, N. J., Mehta, S. \& Tomasi, T. B. (1977) J. Immunol. 118, 723-725

113. Russell-Jones, G. J., Ey, P. L. \& Reynolds, B. L. (1984) Aust. J. Exp. Biol. Med. Sci. 62, 1-10

114. Griffiss, J. M. (1983) Ann. N.Y. Acad. Sci. 409, 697-707

115. Jarvis, G. A. \& Griffiss, M. J. (1989) J. Immunol. 143, 1703-1709

116. Gotze, O. \& Muller-Eberhard, H. J. (1971) J. Exp. Med. 134, 90s

117. Russel, M. W. \& Mansa, B. (1989) Scand. J. Immunol. 30, 175-183

118. Hiemstra, P. S., Biewenga, J., Gorter, A., Stuurman, M. E., Faber, A., van Es, L. A. \& Daha, M. R. (1988) Mol. Immunol. 25, 527-533

119. Spiegelberg, H. L. \& Gotze, O. (1972) Fed. Proc. Fed. Am. Soc. Exp. Biol. 31, 655

120. Boackle, R. J., Pruitt, K. M.\& Mestecky, J.(1974) Immunochemistry 11, 543-548

121. Robertson, J., Caldwell, J. R., Castle, J. R. \& Waldman, R. H. (1976) J. Immunol. 117, 900-903

122. Stewart, W. W., Johnson, A., Steward, M. W., Whaley, K. \& Kerr, M. A. (1988) Mol. Immunol. 25, 1355-1361

123. Miller, G. W. (1976) J. Immunol. 117, 1374-1377

124. Pfaffenbach, G., Lamm, M. E. \& Gigli, I. (1982) J. Exp. Med. 155, 231-247

125a. Rits, M., Hiemstra, P. S., Bazin, H., van-Es, L. A., Vaerman, J. P. \& Daha, M. R. (1988) Eur. J. Immunol. 18, 1873-1880

125b. Rits, M., Kints, J. P., Bazin, H. \& Vaerman, J. P. (1987) Scand. J. Immunol. 25, 359-366

125c. Rits, M., Hiemstra, P. S., Van Es, L. A., Bazin, M., Vaerman, J. P. \& Daha, M. R. (1987) Mol. Immunol. 24, 1047-1053

126. Lesavre, P., Digeon, M. \& Bach, J. F. (1982) Clin. Exp. Immunol. 48, 61-69

127. Waldo, F. B. \& Cochran, A. M. (1989) J. Immunol. 142, 3841-3846

128. Imai, H., Chen, A., Wyatt, R. J. \& Rifai, A. (1988) Clin. Exp. Immunol. 73, 479-483

129. Rifai, A., Chen, A. \& Imai, H. (1987) Kidney Int. 32, 838-844

130. Mellman, I. (1988) Curr. Opin. Immunol. 1, 16-25

131. Abu-Ghazaleh, R. I., Fujisawa, T., Mestecky, J., Kyle, R. A. \& Gleich, G. J. (1989) J. Immunol. 142, 2393-2400

132. Fanger, M. W., Shen, L., Pugh, J. \& Bernier, G. M. (1980) Proc. Natl. Acad. Sci. U.S.A. 77, 3640-3644

133. Fanger, M. W., Goldstine, S. N. \& Shen, L. (1983) Mol. Immunol. 20, $1019-1027$

134. Weisbart, R. H., Kacena, A., Schuh, A. \& Golde, D. W. (1988) Nature (London) 332, 647-648

135. Maliszewski, C. R., Shen, L. \& Fanger, M. W. (1985) J. Immunol. 135, 3878-3881

136. Zipursky, A., Brown, E. J. \& Bienenstock, J. (1973) Proc. Soc. Exp. Biol. Med. 142, 18I-184

137. Kaplan, M. E., Dalmasso, A. P. \& Woodson, M. (1972) J. Immunol. 108, 275-278 
138. Wilson, I. D. (1972) J. Immunol. 108, 726-732

139. Reed, W. P. (1975) Immunology 28, 1051-1059

140. Magnusson, K.-E., Stendahl, O., Stjernstrom, I. \& Edebo, L. (1979) Immunology 36, 439-444

141. Van Epps, D. E., Strickland, R. G. \& Williams, R. C. (1975) Am. J. Med. 59, 200-207

142. Egido, J., Sancho, J., Lorente, F. \& Fontan, G. (1982) Clin. Exp. Immunol. 49, 709-716

143. Van Epps, D. E. \& Brown, S. L. (1981) Infect. Immun. 34, 864-870

144. Henson, P. M., Johnson, H. B. \& Spiegelberg, H. L. (1972) J. Immunol. 109, 1182-1192

145. Walsh, G. M. \& Kay, A. B. (1986) Clin. Exp. Immunol. 63, 466-472

146. Tomino, Y., Miura, M., Suga, T., Endoh, M., Nomoto, Y.\& Sakai, H. (1984) Nephron 37, 137-139

147. Sato, M., Morikawa, K. \& Koshikawa, S. (1983) Clin. Immunol. Immunopathol. 29, 111-118

148. Albrechtesen, M., Yeaman, G. R. \& Kerr, M. A. (1988) Immunology 64, 201-205

149. Fanger, M. W., Pugh, J. \& Bernier, G. M. (1981) Cell. Immunol. 60, 324-334

150. Lawrence, D. A., Weigle, W. O. \& Speigelberg, H. L. (1975) J. Clin. Invest. 55, 368-375

151. Mazengera, R. L. \& Kerr, M. A. (1990) Biochem. J., in the press

151a. Stewart, W. W. \& Kerr, M. A. (1990) Immunology, in the press

152. Sibille, Y., Chatelain, B., Staquet, P., Merrill, W. W., Delacroix, D. L. \& Vaerman, J. P. (1989) Am. Rev. Respir. Dis. 139, 740-747

153. Chevailler, A., Monteiro, R. C., Kubagawa, H. \& Cooper, M. D. (1989) J. Immunol. 142, 2244-2249

154. Reynolds, H. Y., Kazmierowski, J. A. \& Newball, H. H. (1975) J. Clin. Invest. 56, 376-385

155. Monteiro, R. C., Kubagawa, H. \& Cooper, M. P. (1990) J. Exp. Med. 171, 597-613

156. Mota, G., Moraru, I. \& Nicolae, M. (1988) Mol. Immunol. 25, 95-101

157. Johnson, K. J., Wilson, B. S., Till, G. O. \& Ward, P. A. (1984) J. Clin. Invest. 74, 358-369

158. Warren, J. S., Kunkel, R. G., Johnson, K. J. \& Ward, P. A. (1987) Lab. Invest. 57, 311-320

159. Warren, J. S., Kunkel, R. G., Johnson, K. J. \& Ward, P. A. (1987) Am. J. Pathol. 129, 578-588

160. Egido, J., Sancho, J., Rivera, F. \& Sanchez-Crespo, M. (1982) Immunology 46, 1-7

161. Rifai, A. \& Mannik, M. (1983) J. Immunol. 130, 1826-1832

162. Rifai, A. \& Mannik, M. (1984) J. Exp. Med. 160, 125-137

163. Sancho, J., Gonzalez, E. \& Egido, J. (1986) Immunology 57, 37-42

164. Gorter, A., Hiemstra, P. S., Klar-Mohamad, N., van-Es, L. A. \& Daha, M. R. (1988) Immunology 64, 703-708

165. Shen, L. \& Collins, J. (1989) Immunology 68, 491-496

166. Clark, D. A., Dessypris, E. N., Jenkins, D. E. \& Krantz, S. B. (1984) Blood 64, 1000-1005

167. Lowell, G. H., Smith, L. F., Griffiss, J. M. \& Brandt, B. L. (1980) J. Exp. Med. 152, 452-457

168. Steinitz, M., Tamir, S., Ferne, M. \& Goldfarb, A. (1986) Eur. J. Immunol. 16, 187-193

169. Millet, I., Panaye, G. \& Revillard, J.-P. (1988) Eur. J. Immunol. 18, $621-626$
170. Millet, I., Briere, F., Vincent, C., Rousset, F., Andreoni, C., de Vries, J. E. \& Revillard, J. P. (1989) Clin. Exp. Immunol. 76, 268-273

171. Fanger, M. W. \& Lydyard, P. M. (1981) Mol. Immunol. 18, 189195

172. Sakai, H., Miyazaki, M., Endoh, M. \& Nomoto, Y. (1989) Clin. Exp. Immunol. 78, 378-382

173. Raedler, A., Schreiber, S., Schulz, K. H., Peters, S., Greten, H. \& Thiele, H. G. (1988) Adv. Exp. Med. Biol. 237, 665-673

174. Chevailler, A., Monteiro, R. C., Daeron, M. \& Lesavre, P. (1987) Clin. Exp. Immunol. 67, 114-123

175. Adachi, M., Yodoi, J., Masuda, T., Takatsuki, K. \& Uchino, H. (1983) J. Immunol. 131, 1246-1251

176. Gupta, S., Platsoucas, C. D. \& Good, R. A. (1979) Proc. Natl. Acad. Sci. U.S.A. 76, 4025-4029

177. Millet, I., Briere, F., de-Vries, J. \& Revillard, J. P. (1988) Immunol. Lett. 19, 153-157

178. Briere, F., Paliard, X. \& de Vries, J. E. (1988) Eur. J. Immunol. 18, $445-450$

179. Kawanishi, H., Saltzman, L. E. \& Strober, W. (1983) J. Exp. Med. 158, 649-669

180. Benson, E. B. \& Strober, W. (1988) J. Immunol. 140, 1874-1882

181. Kawanishi, H. \& Strober, W. (1983) Mol. Immunol. 20, 917-930

182. Kiyono, H. \& McGhee, J. R. (1987) Int. Rev. Immunol. 2, 157-182

183. Kiyono, H., McGhee, J. R., Mosteller, L. M., Eldridge, J. H., Koopman, W. J., Kearney, J. F. \& Michalek, S. M. (1982) J. Exp. Med. 156, 1115-1130

184. Kiyono, H., Phillips, J. O., Colwell, D. E., Michalek, S. M., Koopman, W. J. \& McGhee, J. R. (1984) J. Immunol. 133, 1087-1089

185. Kiyono, H., Mosteller-Barnum, L. M., Pitts, A. M., Williamson, S. I., Michalek, S. M. \& McGhee, J. R. (1985) J. Exp. Med. 161 731-747

186. Yodoi, J., Adachi, M. \& Noro, N. (1987) Int. Rev. Immunol. 2, $117-141$

187. Millet, I., Samurat, C. \& Revillard, J.-P. (1988) Eur. J. Immunol. $18,545-550$

188. Bich-Thuy, L. T. \& Revillard, J.-P. (1986) Eur. J. Immunol. 16, 156-161

189. Yodoi, J., Adachi, M., Teshigawara, K., Masuda, T. \& Fridman, W. H. (1983) Immunology 48, 551-559

190. Yodoi, J., Adachi, M., Teshigawara, K., Miyama-Inaba, M., Masuda, T. \& Fridman, W. H. (1983) J. Immunol. 131, 303-310

191. Adachi, M., Yodoi, J., Noro, N., Masuda, T. \& Uchino, H. (1984) J. Immunol. 133, 65-71

192. Yodoi, J., Adachi, M. \& Masuda, T. (1982) J. Immunol. 128, 888-894

193. Noro, N., Adachi, M., Yasuda, K., Masuda, T. \& Yodoi, J. (1986) J. Immunol. 136, 2910-2916

194. Tokomoto, H., Shimada, T. Doi, T., Takeuchi, A., Kawabi, T., Yoshida, H. \& Yodoi, J. (1988) Monogr. Allergy 24, 208-214

195. Moore, J. S. \& Hoover, R. G. (1989) J. Immunol. 142, 4282-4288

196. Crago, S. S., Word, C. J. \& Tomasi, T. B. (1989) J. Immunol. 142, 3909-3912

197. Clark, J. A.; Callicoat, P. A., Brenner, N. A., Bradley, C. A. \& Smith, D. M., Jr. (1983) Am. J. Clin. Pathol. 80, 210-213 